\title{
Determinants of Bank Efficiency in ASEAN5: Size as a Control Variable
}

\author{
Randi Anto, Irene Rini Demi Pangestusti", Eriesta Novia Purwandari \\ Department of Management, Faculty of Economics and Business, Universitas Diponegoro, Indonesia
}

Received February 26, 2021; Revised June 15, 2021; Accepted July 19, 2021

\section{Cite This Paper in the following Citation Styles}

(a): [1] Randi Anto, Irene Rini Demi Pangestusti, Eriesta Novia Purwandari, "Determinants of Bank Efficiency in ASEAN5: Size as a Control Variable," Universal Journal of Accounting and Finance, Vol. 9, No. 4, pp. 542-547, 2021. DOI: 10.13189/ujaf.2021.090402.

(b): Randi Anto, Irene Rini Demi Pangestusti, Eriesta Novia Purwandari (2021). Determinants of Bank Efficiency in ASEAN5: Size as a Control Variable. Universal Journal of Accounting and Finance, 9(4), 542-547. DOI: 10.13189/ujaf.2021.090402.

Copyright $C 2021$ by authors, all rights reserved. Authors agree that this article remains permanently open access under the terms of the Creative Commons Attribution License 4.0 International License

\begin{abstract}
Purpose - The purpose of this study was to analyze the effect of Bank Age, Loan to Assets Ratio (LAR), Net Interest Margin (NIM), and non-interest margin (Non NIM) on bank efficiency, especially in ASEAN-5 countries (Indonesia, Singapore, Thailand, Malaysia and Philippines). In this research, bank size was used as a control variable. Design/methodology/approach - The sample of the research was taken form general banking entities listed in each country over the period of 2014-2018. Purposive sampling method was used to select 58 banks as the sample population. We use two-stage methodology in this research by using Data Envelopment Analysis (DEA) to calculate bank efficiency and Multiple Regression Analysis (MRA). Findings- The result showed that capitalization and bank age had a negative significant effect on bank efficiency, while the variable of Loan to Asset Ratio (LAR), Net Interest Margin (NIM) and No-NIM had a positive significant effect on bank efficiency. Originality/value - The measurement of bank efficiency was conducted by utilizing DEA in this study to examine the bank efficiency in ASEAN 5.
\end{abstract}

Keywords Bank Efficiency, Capitalization, Bank Age, Loan to Asset Ratio (LAR), Net Interest Margin (NIM), Non-interest Margin (Non NIM), Data Envelopment Analysis (DEA)

\section{Introduction}

Studies on the determinants of banking efficiency have generally been carried out in developed countries and rarely been done in developing countries. Thus, research in both developed and developing countries is necessary. In line with this, the determinants of efficiency represented by various variables, such Capitalization, Bank Age, and Loans to Assets Ratio (LAR), Net Interest Margin (NIM), and non-interest margin (No-NIM) are in need to be explored.

Previous research of the effect of those variables on the efficiency often results in inconsistency. For example, Ab-Rahim et al., [1]; Pasiouras et al., [2]; and Cavallo \& Rossi [3] find a negative relationship between capitalization and bank efficiency while Partovi \& Matousek [4]; Fernandes et al., [5]; Sufian et al., [6]; Mamatzakis et al., [7] show the opposite result. In the concept of learning by doing in research of Partovi \& Matousek [4]; Sinaga et al., [8] bank age affects bank efficiency positively. However, this is not in line with the findings of Adeabah et al., [9] and Fukuyama \& Matousek [10]. Batir et al., [11]; Garza-Garcia [12]; and Sufian \& Noor [13] show that Loans to Assets Ratio has a positive effect on efficiency, in which it contradicts the findings of Fernandes et al., [5]; Ahmad \& Noor [14] and Maudos et al., [15]. Net Interest Margin (NIM) in the research of Partovi \& Matousek [4] shows a positive effect on efficiency, but this is contrary to the findings of Fukuyama and Matousek [10]. Other factors such as No-NIM have a positive influence on efficiency Fukuyama \& Matousek [10], whereas, according to the research of Partovi \& Matousek [4], No-NIM has a negative effect on bank efficiency. 
The inconsistency of the previous research findings indicated a research gap that needs further investigation. Therefore, the aim of this study was to analyze the effect of Bank Age, Loan to Assets Ratio (LAR), Net Interest Margin (NIM), and No-NIM on banks efficiencies, especially in ASEAN-5 countries (Indonesia, Singapore, Thailand, Malaysia and Philippines). Moreover, the finding is expected to be useful for policy makers of both the government and the banking sector in determining policies that can optimize banking efficiency.

\section{Literature Review and Hypotheses}

In their research, Ab-Rahim et al., [1]; Pasiouras et al., [2]; Dell'Atti et al., [16] confirmed a negative relationship between capitalization and bank efficiency. According to the regulatory hypothesis, the existence of a regulator enables banks to be more efficient and well managed as the banks have a low capitalization rate. Banks with moderate levels of capitalization potentially easier to manage and monitor credit quality so that asymmetric information can be minimized and the banks become more efficient [16]. Bank capital, part of which comes from deposits, in addition to generating interest when channeled in the form of credit, could also create a relatively large cost of funds if it was not managed properly. Based on these reasons, we concluded that capitalization has a negative effect on efficiency. Therefore, hypothesis 1 is written as follows:

\section{H1: There is a negative effect of capitalization on bank} efficiency

The result of the research conducted by Fukuyama \& Matousek [10] and Adeabah et al., [9] empirically proved a negative relationship between bank age and bank efficiency. The aging banks have a tendency to decline in governance, as they have aging assets, lower margins, and higher costs. According to Leonard-Barton [17], the decline in governance along with the aging banks results in the banks not being able to manage their resources optimally, leading the banks to become less efficient. Furthermore, they explained that older banks tend to be more rigid in carrying out banking activities or becoming obsolescence due to the lack of innovation, so they lose their competitiveness which results in the banks to be inefficient. Based on these reasons, we concluded that bank age has a negative effect on efficiency. Thus, hypothesis 2 is formulated as follows:

H2: There is a negative effect of bank age on bank efficiency

In their studies, Batir et al., [11]; Garza-Garcia [12]; and Sufian \& Noor [13] identified a positive relationship between LAR and bank efficiency. The positive relationship between lending activities and bank efficiency is related to the ability of the banks that relatively efficient in managing their operational activities productively so that they can reduce costs. The ability of the banks to carry out operational activities at lower costs leads them to be able to offer loan terms that are accepted by customers so that their market share will be getting bigger [13]. According to Isik \& Hassan [18], the market power of loans is the result of the efficient operations. The higher the loan distributed by the bank was, the higher the rate of return would be. As a result, the production scale would increase and the banks would become more efficient. In addition, the costs of managing customers borrowing big and small loan would be the same in several ways, such as audit fees and notary fee. Based on these reasons, we concluded that LAR has a positive effect on efficiency. Thus, hypothesis 3 is written as follows:

\section{H3: There is a positive effect of Loans to Assets Ratio} on bank efficiency

Partovi \& Matousek [4] and Mamatzakis et al., [7] found a positive relationship between Net Interest Margin (NIM) on bank efficiency, and Fukuyama \& Matousek [10] confirmed that NIM has the ability to ascertain the quality of management in managing deposits to generate net income. Fukuyama \& Matousek [10] further explained that NIM may also be able to shape quality banking and can be used to evaluate banks in managing risks that may occur at interest rates. The higher the ratio the NIM of the bank indicates, the less the bank is likely to have problems. Based on these reasons, we concluded that NIM has a positive effect on efficiency. So, hypothesis 4 is written as follows:

\section{H4: There is a positive effect of NIM on bank efficiency}

Research conducted by Fukuyama \& Matousek [10] found a positive relationship between non-interest margin (No-NIM) and bank efficiency. No-NIM reflected the management quality in controlling assets owned by the bank in generating non-interest derived income. The non-interest income of the bank can be obtained from banking activities other than lending as the main function of banking, which is generally called fee-based income [19]. The higher the No-NIM ratio indicated that the bank had a good management quality, as it could control its assets to generate additional income in the form of non-interest income net. The non-interest income, according to Smith et al., [20] can stabilize bank income. Based on these reasons, we concluded that No-NIM has a positive effect on efficiency. Therefore, hypothesis 5 is written as follows:

H5: There is a positive effect of the variable of No-NIM on bank efficiency. 


\section{Method}

The data used in this study were the banks participated in this study were commercial banks listed in the stock exchanges in the respective ASEAN-5 countries. The bank participated in this study had financial statements with the financial reporting period from 2014 to 2018 that could be accessed at the Bloomberg. This study was conducted by using purposive sampling method. The number of samples used in this study was 64 banks. In detail, the number of samples from Indonesia was 32 banks, Singapore ( 3 banks), Thailand (9 banks), Malaysia ( 8 banks), and the Philippines (11 banks). The period of the data used in this research was 5 years, from 2014 until 2018.

This study examined the effect of the independent variable on the dependent variables using control variables. The dependent variable was bank efficiency, the independent variables were capitalization, age, Loan to Assets Ratio (LAR), Net Interest Margin (NIM), and No-NIM, and the control variable was bank size.

The operational definition of the variables used in this study is as follows. Efficiency is the ratio of the number of weighted output to the number of weighted inputs [11]. The input used in calculating efficiency consisted of Total Capital and Total Deposit. Meanwhile, the output used in calculating efficiency consisted of the desired output, namely Total Loans and Non-Interest Income as well as Non-Performing Loans (NPL) as unwanted output. Capitalization is defined as the ratio obtained from the Total Capital at Tier 1 and Tier 2 of the bank concerned divided by total assets [4]. Bank Age is defined as since when a bank has operated or as a representation of the number of years a bank has joined to become a financial institution [9]. Loan to Assets Ratio (LAR) is defined as the ratio of total loans disbursed by banks to assets owned by the bank [5]. Net Interest Margin (NIM) is represented as Net Interest Income compared to total deposits [4]. Non-interest margin (No-NIM) is represented as net non-interest income divided by total assets [4]. Lastly, Bank Size is defined as the size of a bank based on the number of assets owned. Bank size is represented as the natural log of total assets [21].

In this study, the level of banking efficiency was measured and the determinants affecting banking efficiency were examined using two steps of analysis technique. The first step was to calculate bank efficiency by comparing the weighted average number of outputs against the weighted average number of inputs using Data Envelopment Analysis. The second step was to perform multiple regression analysis to determine the effect of the independent variable on the dependent variables. This study applied 2 equations of multiple regression analysis models consisting of model 1 (without control variables) and model 2 (with control variables). The regression equation used is as follows:
Model 1 (Without Control Variable):

Efficiency $=\beta 0+\beta 1$ Capitalization $+\beta 2$ Age $+\beta 4$ LAR + $\beta 5 \mathrm{NIM}+\beta 6 \mathrm{No}-\mathrm{NIM}+\varepsilon$

Model 2 (With Control Variable):

Efficiency $=\beta \mathrm{o}+\beta 5$ Capitalization $+\beta 6$ Age $+\beta 7 \mathrm{LAR}+$ $\beta 8 \mathrm{NIM}+\beta 9$ No-NIM $+\beta 10 \mathrm{Size}+\varepsilon$

Information: Efficiency $=$ Bank Efficiency; Capitalization $=$ Capitalization Rate; Size $=$ Bank Size; Age $=$ Bank Age $;$ NIM = Net Interest Margin; No-NIM = Non-interest margin; $\beta 0=$ Constant; $\beta 1, \ldots, \beta 10=$ the coefficient of each variable; $\varepsilon=$ Error

\section{Result and Discussion}

The data in this study were analyzed based on the rules for conducting multiple regression analysis. The regression equation must have data that are normally distributed and free from symptoms of heteroscedasticity, multicollinearity, and autocorrelation. Table 1 shows the results of the residual normality test in which the data without control variables and with control variables were normally distributed, as the Kolmogorov-Smirnov was greater than $5 \%$.

Table 1. Result of Residual Normality Test (Kolmogorov-Smirnov Z Statistics)

\begin{tabular}{ccc}
\hline & $\begin{array}{c}\text { Without Control } \\
\text { Variable }\end{array}$ & $\begin{array}{c}\text { With Control } \\
\text { Variable }\end{array}$ \\
\hline Residual Values & 0.139 & 0.069
\end{tabular}

Next, the result of the Durbin Watson test of the data without control variable was 2.078 , or less than 2.1645 (4-du) but greater than 1.779 (du). Meanwhile, the result of the Durbin Watson test of data with control variable was 2.077 , or less than 2.1573 (4-du) but greater than $1.8426(\mathrm{du})$. Thus, the data in this study were free from autocorrelation symptoms. Table 2 shows the results of the multicollinearity test of the research data with and without control variables. The result showed that the data in this study were free from multicollinearity symptoms because the Variance Inflation Factor (VIF) of each variable used had a value of less than 10 .

Table 2. Result of Multicollinearity Test

\begin{tabular}{ccc}
\hline Variable & $\begin{array}{c}\text { Without Control } \\
\text { Variable }\end{array}$ & $\begin{array}{c}\text { With Control } \\
\text { Variable }\end{array}$ \\
\hline Capitalization & 1.093 & 1.094 \\
Bank Age & 1.033 & 1.033 \\
LAR & 1.039 & 1.064 \\
NIM & 1.116 & 1.225 \\
No-NIM & 1.080 & 1.187 \\
Bank Size & & 1.238 \\
\hline
\end{tabular}

Table 3 shows the results of the Park Test of the research data with and without control variables. The 
result showed that the data in this study were free from heteroscedasticity symptoms because all independent variables had a significance value which was greater than $5 \%$.

Table 3. Result of Park Test

\begin{tabular}{ccc}
\hline Variable & $\begin{array}{c}\text { Without Control } \\
\text { Variable }\end{array}$ & $\begin{array}{c}\text { With Variable } \\
\text { Control }\end{array}$ \\
\hline Capitalization & 0.391 & 0.548 \\
Age & 0.480 & 0.400 \\
LAR & 0.060 & 0.060 \\
NIM & 0.051 & 0.358 \\
No-NIM & 0.127 & 0.756 \\
Size & & 0.075 \\
\hline
\end{tabular}

The results of the normality test in this study indicated that the data used were normally distributed and free from the symptoms of heteroscedasticity, multicollinearity, and autocorrelation. Thus, the data in this study met the requirements for multiple regression analysis.

The next testing was to examine Multiple Regression Analysis. The t-test was conducted to answer problems of the study to achieve the objectives of the study, test the research hypothesis, and determine whether the independent variables partially had a significant effect on the variables of the study. Table 4 presents the results of the multiple regression analysis related to the $t$ test and the coefficient of determination in model 1 (without control variables) and in model 2 (with control variables).

Table 4. Results of Regression

\begin{tabular}{ccc}
\hline & $\begin{array}{c}\text { Without Control } \\
\text { Variable }\end{array}$ & $\begin{array}{c}\text { With Control } \\
\text { Variable }\end{array}$ \\
\hline Capitalization & $-0.485^{* * *}$ & $-0.480 * * *$ \\
Age & $-5.079 * * *$ & $-5.079 * * *$ \\
LAR & $0.219 * * *$ & $0.231 * * *$ \\
NIM & $0.558 * * *$ & $0.672 * * *$ \\
No-NIM & $4.449 * * *$ & $3.995 * * *$ \\
Size & & $0.004 *$ \\
Constant & 0.816 & 0.764 \\
Observation & 290 & 290 \\
Adjusted $\mathrm{R}^{2}$ & 0.193 & 0.263 \\
\hline
\end{tabular}

$* * *=$ significant at $1 \% ; * *=$ significant at $5 \% ; *=$ significant at $10 \%$

Based on the results of the $t$ statistical test as presented in Table 4, the multiple regression equation model 1 (without control variables) was formulated as follows:

$$
\begin{gathered}
\text { Efficiency }=0.816-0.485 \text { Capitalization }-5.079 \text { Age }+ \\
0.219 \text { Age }+0.558 \text { NIM }+4.449 \text { No-NIM }
\end{gathered}
$$

Furthermore, based on Table 4, the multiple regression equation for model 2 (with control variables) was formulated as follows:

Efficiency $=0.764-0.480$ Capitalization -5.079 Age + $0.231 \mathrm{LAR}+0.672 \mathrm{NIM}+3.995 \mathrm{No}-\mathrm{NIM}+0.004$ Size
The results showed that the coefficient value of the variable of capitalization, LAR, Net Interest Margin, and Non-interest margin changed. The coefficient value of the capitalization variable in model 1 (without control variables) was -0.485 ; then, it changed to 0.480 in model 2 (with control variables). The coefficient value of the Loans to Assets Ratio variable in model 1 was 0.219 ; then it changed to 0.231 in model 2 or after control variable existed. Meanwhile, the coefficient value of the NIM variable with the regression equation model without control variables was 0.558 , but after the control variable existed, it changed into 0.672. Furthermore, in the No-NIM variable, the coefficient value in the regression equation without control variables was 4.449 ; then, it changed to 3.995 in the regression equation with control variables.

In Table 4, the value of the coefficient of determination (Adjusted R2) changed after the control variable existed. In model 1, it was 0.193 or $19.3 \%$, meaning that $19.3 \%$ of the bank efficiency variable in this study could be explained by the variables of Capitalization, Bank Age, Bank Size, LAR, NIM and Non NIM while the remaining $80.7 \%$ could be explained by other factors outside this research model. Meanwhile, as the coefficient of determination (Adjusted R2) in model 2 was 0.263 or $26.3 \%, 26.3 \%$ of bank efficiency in this study could be explained by Capitalization, Bank Age, LAR, NIM, No-NIM, and Bank Size while the remaining $73.7 \%$ was explained by other factors outside the research model. The changes in the coefficient of determination in models 1 and 2 suggested that the control variable of Size had a role in increasing the ability of the model to explain the effect of the independent variable on the dependent variables. The control variable, bank size, was able to increase the ability of the model to explain efficiency by $7 \%$.

The results confirmed that capitalization variable had a significant negative effect on bank efficiency with the $t$ value of 0.480 at $1 \%$ significance level. Therefore, $\mathrm{H} 1$, capitalization has a negative effect on bank efficiency, was empirically supported. Furthermore, the variable of the age of the bank had a negative significant effect on bank efficiency with the $t$ value of 5.079 at a significance of $1 \%$. Therefore, $\mathrm{H} 2$, bank age has a negative effect on bank efficiency, was empirically supported.

The statistical of the effect of Loans to Assets Ratio (LAR) variable is empirically proven to have a positive effect on bank efficiency with the $t$ value of 0.231 at a significance of $1 \%$. Thus, H3, LAR has a positive effect on bank efficiency, was supported empirically. These findings implied that the higher the ratio of loans extended by banks to assets owned by banks is, the more efficient the bank will be. Net Interest Margin (NIM) had a positive effect on bank efficiency with the $t$ value of 0.672 at a significance of $1 \%$. Therefore, H4, NIM has a positive effect on bank efficiency, was supported empirically. These findings proposed that the higher the bank's net interest income margin is, the more efficient the bank will 
be. Lastly, the variable of no-NIM had a positive effect on bank efficiency with the $t$ value of 3.995 at a significance of $1 \%$. So, H5, No-NIM has a positive effect on bank efficiency, was supported empirically. These findings showed that the higher the net non-interest income margin is, the more efficient the bank will be.

\section{Conclusions}

All independent variables examined in this study, such as capitalization, bank age, Loans to Assets Ratio (LAR), Net Interest Margin (NIM), and No-NIM have a significant effect on bank efficiency, either partially or as a whole. Capitalization and bank age have a negative effect on bank efficiency, whereas Loans to Assets Ratio, Net Interest Margin (NIM), and No-NIM have a positive effect on efficiency.

Based on the results of this research, banks are advised to consider their capital so that it can be optimized and banks can still operate efficiently. Banks are advised to make innovations in terms of both business and operational products, such as developing banking technology and enhancing human resource competence. As they get older, banks are also expected to make improvements in governance so that banking operations can be optimized and banks become more efficient. In addition, banks need to increase the amount of loans extended to qualified customers so that it will increase the rate of return on assets which can increase the scale of bank production and result in banks becoming more efficient.

\section{REFERENCES}

[1] Ab-Rahim R, Md-Nor NG, Ramlee S, Ubaidillah NZ, "Determinants of cost efficiency in Malaysian banking," International Journal of Business and Society, vol. 13, no. 3, pp. 355-374, 2012.

[2] Pasiouras F, Tanna SK, Zopounidis C, "Regulations, Supervision and Banks' Cost and Profit Efficiency Around the World: A Stochastic Frontier Approach," University of Bath Management Working Paper, no. 2007.05, 2007. https://dx.doi.org/10.2139/ssrn.970373.

[3] Cavallo L, Rossi SP, "Do environmental variables affect the performance and technical efficiency of the European banking systems? A parametric analysis using the stochastic frontier approach," The European Journal of Finance, vol. 8, no. 1, pp. 123-146, 2002.

[4] Partovi, E., \& Matousek, R, "Bank efficiency and non-performing loans: Evidence from Turkey," Research in International Business and Finance, 48(March (2018), pp. 287-309,

2019. https://doi.org/10.1016/j.ribaf.(2018).12.011

[5] Fernandes, F. D. S., Stasinakis, C., \& Bardarova, V,
"Two-stage DEA-Truncated Regression: Application in banking efficiency and financial development," Expert Systems with Applications, 96, pp. 284-301, 2018. https://doi.org/10.1016/j.eswa.(2017).12.010

[6] Sufian, F., Kamarudin, F., \& Nassir, A. md, "Determinants of efficiency in the malaysian banking sector: Does bank origins matter?" Intellectual Economics, 10(1), pp. 38-54, 2016. https://doi.org/10.1016/j.intele.(2016).04.002

[7] Mamatzakis, E., Matousek, R., \& Vu, A. N, "What is the impact of bankrupt and restructured loans on Japanese bank efficiency?" Journal of Banking and Finance, 72, S187S202,

2016.

https://doi.org/10.1016/j.jbankfin.(2015).04.010

[8] Sinaga, J. S., Muda, I., \& Silalahi, A. S, "The effect of BI rate, exchange rate, inflation, and third-party fund (DPK) on credit distribution and its impact on non-performing loan (NPL) on XYZ commercial segment bank," Universal Journal of Accounting and Finance, 8(3), pp. 55-64, 2020. DOI: $10.13189 /$ ujaf.2020.080301

[9] Adeabah, D., Gyeke-Dako, A., \& Andoh, C, "Board gender diversity, corporate governance and bank efficiency in Ghana: a two stage data envelope analysis (DEA) approach," Corporate Governance (Bingley), 19(2), pp. 299-320, 2017. https://doi.org/10.1108/CG-08-(2017)-0171

[10] Fukuyama, H., \& Matousek, R, "Efficiency of Turkish banking: Two-stage network system. Variable returns to scale model," Journal of International Financial Markets, Institutions and Money, 21(1), pp. 75-91, 2011. https://doi.org/10.1016/j.intfin.2010.08.004

[11] Batir, T. E., Volkman, D. A., \& Gungor, B, "Determinants of bank efficiency in Turkey: Participation banks versus conventional banks," Borsa Istanbul Review, 17(2), pp. 8696, 2017. https://doi.org/10.1016/j.bir.(2017).02.003

[12] Garza-Garcia, "Determinants of bank efficiency in Mexico: a two-stage analysis," Centre for Global Finance for Global Finance, 2014.

[13] Sufian, F., \& Noor, M. A. N. M, "The determinants of Islamic banks' efficiency changes: Empirical evidence from the MENA and Asian banking sectors," International Journal of Islamic and Middle Eastern Finance and Management, 2(2), pp. 120-138, 2009.

[14] Ahmad, N. H., \& Noor, M. A. N. M, "The Determinants Efficiency and Profitability of World Islamic Banks," International Conference on E-Business, Management and Economics, 3, pp. 228-233, 2011.

[15] Maudos, J., Pastor, J. M., Pérez, F., \& Quesada, J, “Cost and profit efficiency in European banks," Journal of International Financial Markets, Institutions and Money, 12(1), pp. 33-58, 2002. https://doi.org/10.1016/S1042-4431(01)00051-8

[16] Dell'Atti, S., Pacelli, V., \& Mazzarelli, G, "The efficiency of the European banking groups and its determinants," Managerial Finance, 41(7), pp. 734-751, 2015 https://doi.org/10.1108/MF-12-2013-0335

[17] Leonard - Barton, D, "Core capabilities and core rigidities: A paradox in managing new product development," Strategic Management Journal, 13(1 S), pp. 111-125, 1992, https://doi.org/10.1002/smj.4250131009 
[18] Isik, I., \& Hassan, M. K, "Efficiency, ownership and market structure, corporate control and governance in the Turkish banking industry," Journal of Business Finance and Accounting, 30(9-10), pp. 1363-1421, 2003. https://doi.org/10.1111/j.0306-686X.(2003).05533.x

[19] Kasmir, "Dasar-Dasar Perbankan,” Jakarta. PT Raja Grafindo Persada, 2002.
[20] Smith, R., Staikouras, C., \& Wood, G. E, "Non-Interest Income and Total Income Stability," SSRN Electronic Journal, 198, 2011. https://doi.org/10.2139/ssrn.530687

[21] Banna, H., Shah, S. K. B., Noman, A. H. M., Ahmad, R., \& Masud, M. M, "Determinants of Sino-Asean banking efficiency: How do countries differ?" In Economies, Vol. 7, Issue 13, pp. 1-23, 2019,

https://doi.org/10.3390/economies7010013 